\title{
Interrelationship between vitality of ectomycorrhizae and occurrence of microfungi
}

\author{
T. Ritter, G. Weber, I. Haug, I. Kottke and F. Oberwinkler
}

Universität Tübingen, Institut für Biologie I, Spezielle Botanik und Mykologie, Auf der Morgenstelle 1, D-7400 Tübingen, F.R.G.

\section{Introduction}

In connection with forest decline, root-soil interactions are frequently discussed. Up to now, it has been difficult to classify the vitality of ectomycorrhizae and less attention has been paid to the microfungal flora associated with the roots. Thus occurrence and species diversity of microfungi of the rhizoplane and the interior of the mycorrhizae have been investigated in two plots, which differed in their degree of canopy damage. In parallel studies, the vitality of ectomycorrhizae was evaluated by vital staining with fluorescein diacetate (FDA).

\section{Materials and Methods}

The sites

The testing ground Ziefle is situated in the northern Black Forest near Alpirsbach. On slightly gleyic brown earth of red sandstone, a stand of 70-80 yr old Norway spruce (Picea abies (L.) Karst.) and silver fir (Abies alba Mill.) is located. One part of the area was limed in 1975 with $30 \mathrm{dt} / \mathrm{ha}$ 'Hüttenkalk'. On the limed plot, trees are generally healthy, whereas on the unlimed plot, severe yellowing and loss of needles can be observed. A characterization of the limed and unlimed plots is given in Table I.

\section{Determination of mycorrhizal vitality}

Root samples were taken strictly related to defined trees, i.e., one representative silver fir ( $A$. alba Mill.) and one representative Norway spruce ( $P$. abies (L.) Karst.) from each plot at irregular time intervals between May 1985 and August 1987.

Vitality of ectomycorrhizae was ascertained under the fluorescence microscope after vital staining with FDA. Since only living cells give a light green fluorescent response to FDA-vital staining (Rotman and Papermaster, 1966; Ziegler et al., 1975), this technique provides detailed information about the physiological status

Table I. Characterization of the Ziefle testing ground.

\begin{tabular}{|c|c|c|c|c|c|}
\hline & $\begin{array}{l}\text { Needle loss } \\
\text { (in \%) }\end{array}$ & $\begin{array}{l}\text { Yellowing } \\
\text { of needles }\end{array}$ & $\begin{array}{l}\mathrm{pH}\left(\mathrm{H}_{2} \mathrm{O}\right) \\
\text { humus layer }\end{array}$ & $\begin{array}{l}M g\left(\mu e q \cdot g^{-1}\right) \\
\text { humus layer }\end{array}$ & $\begin{array}{l}\text { Ca ( }\left(\mu e q \cdot g^{-1}\right) \\
\text { humus iayer }\end{array}$ \\
\hline unlimed & $50-90$ & frequent & $3.7^{\star}$ & $8.4^{\star}$ & $22.2^{*}$ \\
\hline limed & $10-25$ & seldom & $4.7^{*}$ & $54.1^{\star}$ & $143.2^{\star}$ \\
\hline
\end{tabular}

\footnotetext{
* From Aldinger (1987).
} 
of ectomycorrhizae (Ritter et al., 1986). Based on vital staining with FDA, 5 stages of ectomycorrhizal vitality could be differentiated (see below). The vitality of the mycorrhizae of damaged and healthy trees was compared by analyzing a random sample of 120-150 mycorrhizal root tips per tree and date of sampling (see below).

\section{Isolation of microfungi}

Mycorrhizal roots of spruce were collected from the upper humus layer beneath the surface litter of the 2 sites at monthly intervals, during the 2 yr investigation period. Suitable sections of mycorrhizae were excised and subjected to a serial washing procedure, adapted from the methods of Harley and Waid (1955) and Gams and Domsch (1967). For the isolation of fungi from the inner root, surface sterilization after washing was used. Root pieces were then plated on MEA ( $2 \%$ malt extract-agar with 500 ppm of streptomycin sulfate) and CMC-agar (Söderström and Båăth, 1978). The plates were incubated at $15^{\circ} \mathrm{C}$ for 2 wk in the dark, and for at least another $4-6 \mathrm{wk}$ at $21^{\circ} \mathrm{C}$ in light. As fungal colonies became established, inocula were transferred to suitable nutrient media and incubated at $21^{\circ} \mathrm{C}$ for subsequent determination.

\section{Infection tests with spruce seedlings}

Infection tests were carried out with spruce ( $P$. abies (L.) Karst.) grown sterilely in Petri dishes on filter paper (for a detailed description, see Haug et al., 1988). Three week old spruce seedlings were inoculated with a fungus, Cryptosporiopsis abietina Petrak, which was isolated earlier with high frequency from surface-sterilized roots. The experiment lasted 6 mo.

\section{Results}

\section{Vitality of mycorrhizae}

\section{Stages of ectomycorrhizal vitality (Fig. 1)}

Stage 1. Entirely active mycorrhizae $(+++)$ : all regions (hyphal sheath, cortex including the Hartig net, vascular cylinder and meristematic region) are active.

Stage 2. Largely active mycorrhizae $(++)$ : the outer cortical cells and a larger part of the hyphal sheath have lost vitality. The activity of the hyphal sheath is preserved around the apical meristem.

Stage 3. Mycorrhizae of reduced activity $(+)$ : living cells only in the vascular cylinder and the meristematic region. Dead cells of the cortex, as well as the hyphal sheath, are frequently colonized intracellularly by fungi.

Stage 4. Dying mycorrhizae $(+/-)$ : decrease of the vascular and meristematic tissues, starting at the apex and then moving back to the basis of the rootlet.

Stage 5. Dead mycorrhizae (-): all root cells are intracellularly colonized by fungi.

Vitality of the mycorrhizal systems of trees from the limed and the unlimed plots

Significant differences in mycorrhizal vitality were observed between trees from the
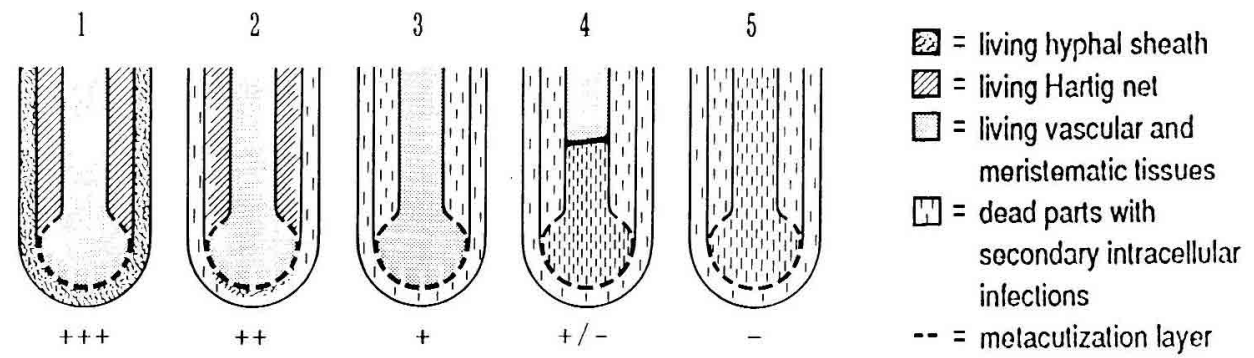

Fig. 1. Stages of ectomycorrhizal vitality. 

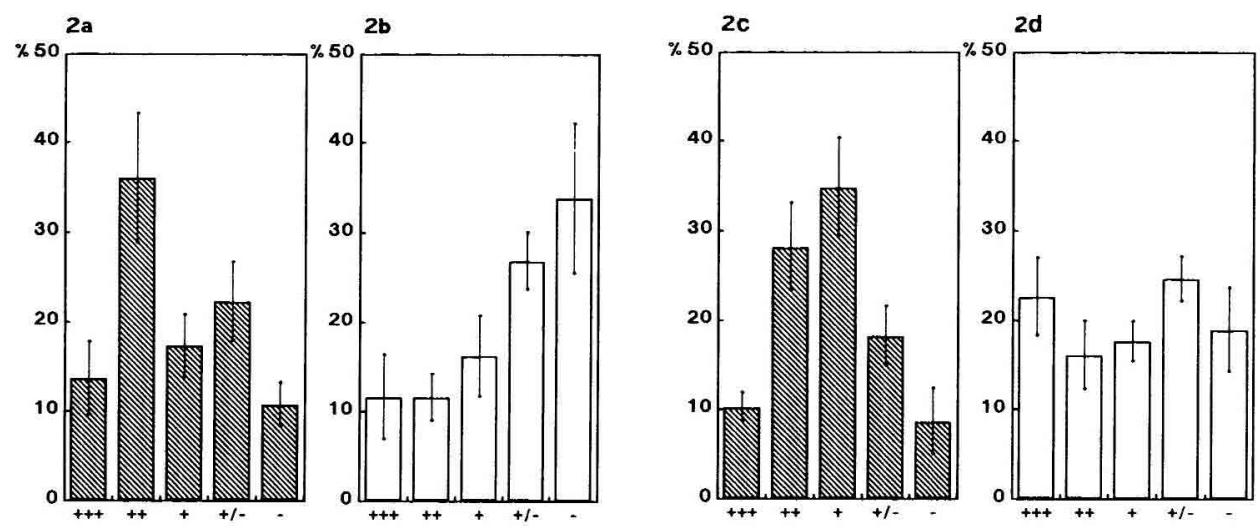

Fig. 2. Frequency of the 5 stages of ectomycorrhizal vitality as the percentage of the total number of analyzed mycorrhizae/tree. The percentage values in each treatment add up to $100 \%$, a, b: Norway spruce. c, d: Silver fir. $x$ axis: vitality corresponding to the explanations given in the text. Ordinate values: means and standard deviation of 6 samples between May 1985 and July 1987. Shading indicates healthy trees (limed plot. Fig. 2a, 2c). Unshaded indicates damaged trees (unlimed plot, Fig. 2b, 2d).

unlimed and the limed plots (Fig. 2). On the unlimed plot (Fig. 2b, d), the percentage of ectomycorrhizae with full vitality (stage 1) as well as the percentage of dying and dead mycorrhizae (stages 4 and 5) were higher compared to the limed plot (Fig. 2a, c). However, mycorrhizae of medium vitality (stages 2 and 3 ) could be detected more often on the limed plot. The highest amounts of dying and dead very fine roots were found in the extremely damaged Norway spruce from the unlimed plot (Fig. 2b).

\section{Microfungi from the rhizoplane}

Forty-four fungal species, belonging to 25 genera, were isolated from the rhizoplanes of mycorrhizae. The most abundant genera were Trichoderma, Cylindrocarpon, Penicillium, Oidiodendron, Thysanophora and the form genus Mycelium radicis atrovirens.

\section{Differences in species number}

From the mycorrhizae of the quite healthy spruces on the limed plot, more species were isolated than from the mycorrhizae of the heavily damaged spruces on the non-limed plot (Fig. 3).

\section{Differences in species composition}

Differences in the microfungal flora from root surfaces of spruce on the 2 plots occurred not only in species number, but also in species composition. A comparison of the dominant species from the 2 stands showed that, on mycorrhizae of the damaged trees, 2 fungal species were dominant. Among them, certain strains are known as root pathogens, Cylindrocarpon destructans (Zinssm.) Scholten and Trichoderma viride Pers. ex Gray. These two species were also present in the rhizoplanes from the limed stand, but at a lower frequency (Fig. 4).

Remarkable at this limed stand is the dominance of two saprobe species, 


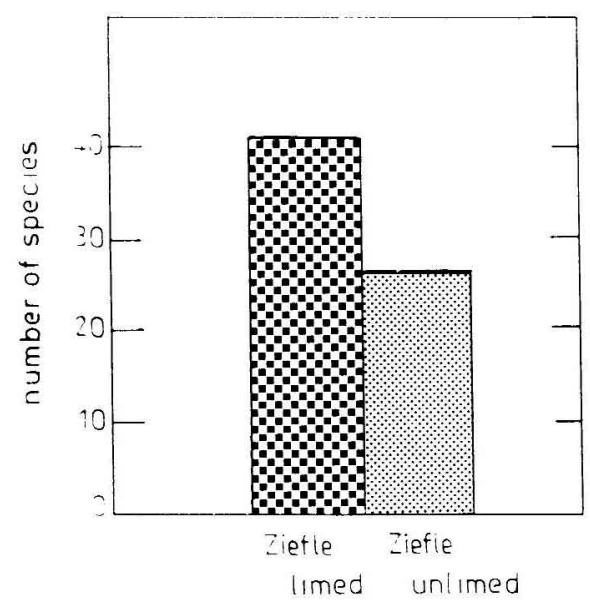

Fig. 3. Number of rhizoplane fungal species at the limed and unlimed 'Ziefle' plots.

Oidiodendron aff. griseum Robak and Thysanophora penicilloides (Roum.) Kendrick, which showed an antagonistic behavior against various Cylindrocarpon destructans strains in paired culture test series.

\section{Microfungi in the mycorrhizae}

Infection of mycorrhizae of the unlimed spruce stand (for figures see Haug et al., 1988)

Examination of mycorrhizae with dark roots tips from the unlimed spruce stand by light and electron microscopy revealed a heavy intracellular fungal infection of cortex cells, vascular tissue and meristem. Hyphal mantle, cortex and Hartig net of infected mycorrhizae were dead. Within the vascular tissue, different stages of infection could be detected. At an early stage, only a few cells contained several hyphae. At a more advanced stage, hollow spaces with large amounts of mycelia were found, surrounded by cells filled with tannins. The intracellular hyphae were septate and showed simple pores with Woronin bodies. They could thus be identified as Ascomycetes. No intracellular infection was found in mycorrhizae with light-colored root tips and living hyphal mantles.

\section{Isolation of pathogenic fungi and infection} tests

From 96 surface-sterilized mycorrhizae from the unlimed plot, 17 isolates of fungi with septate hyphae were made. Two species could be distinguished: Mycelium radicis atrovirens Melin and Cryptosporiopsis abietina Petrak. Infection tests with Cryptosporiopsis abietina and spruce seedlings revealed severe infection of cortex and vascular tissues, resulting in a decline of the spruce seedlings. Quite often the cell structure of cortex and vascular tissues was destroyed and large areas of the roots were consumed by a dense network of hyphae. Cryptosporiopsis abietina can thus be considered to be responsible for the intracellular infection of the vascular tissue of the investigated spruce roots from the Ziefle site.
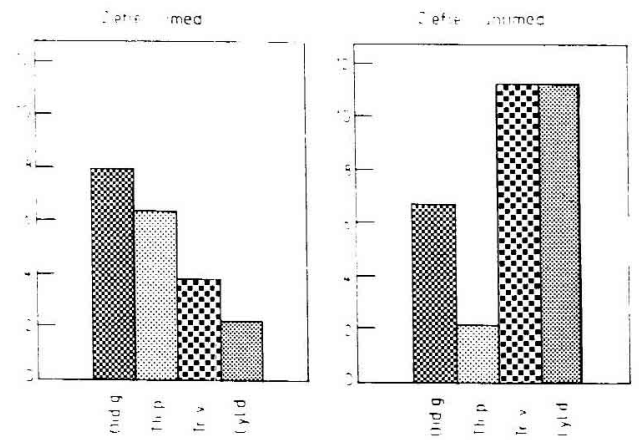

Fig. 4. Frequency of isolation of some pathogenic and antagonistic rhizoplane fungi at the limed and unlimed 'Ziefle' plots (recorded as percentage incidence from the total isolates of each plot). Oid.g. = Oidiodendron aff. griseum; Th.p. = Thysanophora penicilloides; Tr.v. = Trichoderma viride; Cyl.d. = Cylindrocarpon destructans. 


\section{Discussion}

In mature forest stands, only small increments of fine root biomass can be observed because, in the annual balance, fine root loss due to normal aging and fine root production are almost in equilibrium (Grier et al., 1980). In the actual paper, the dynamic equilibrium between young and senescent fine roots is illustrated by the distribution of the 5 stages of ectomycorrhizal vitality, since these stages represent phases in the process of aging of mycorrhizae (Ritter et al., 1989). The low percentage of mycorrhizae of medium vitality $('++$ ', ' + ') and the higher percentage of dying and dead mycorrhizae ('+l-', '-') from trees on the unlimed plot indicate a more rapid ageing and a higher turnover rate of very fine roots of these trees. In contrast, from trees on the limed plot, the vascular and the meristematic tissues of mycorrhizae retained vitality for a relatively long time after the hyphal sheath ('++') or the hyphal sheath and the Hartig net (' + ') had died.

The increase of dying and dead mycorrhizae (stages 4 and 5) was paralleled by an increase of pathogenic fungal species from the rhizoplanes or inner root on the unlimed plot. One interpretation of this fact might be that, on the unlimed plot, the protective effect of mycorrhizae is reduced. As a result, pathogenic fungi can establish themselves more easily on the rhizoplane, resulting in an increased penetration of the root tissue. Thus it can be concluded that there exists an interrelationship between the vitality of the mycorrhizae, the root mycoflora and the occurrence of pathogens of the rhizoplane and the interior of mycorrhizae.

\section{References}

Aldinger E. (1987) Elementgehalte im boden und in nadeln verschieden stark geschädigter fichten-tannen-bestände auf praxiskalkungsflächen im buntsandstein-schwarzwald. Dissertation Freiburg

Gams W. \& Domsch K.H. (1967) Beiträge zur anwendung der bodenwaschtechnik für die isolierung von bodenpilzen. Arch. Mikrobiol. 58, 134-144

Grier C.C., Vogt K.A., Keyes M.R. \& Edmonds R.L. (1980) Biomass distribution and aboveand below-ground production in young and mature Abies amabilis zone ecosystems of the Washington cascades. Can. J. For. Res. 11, 155-167

Harley J.L. \& Waid J.S. (1955) A method of studying active mycelia on living roots and other surfaces in the soil. Trans. Br. Mycol. Soc. 38, 104-118

Haug I., Weber G. \& Oberwinkler F. (1988) Intracellular infection by fungi in mycorrhizae of damaged spruce trees. Eur. J. For. Pathol. 18, $112-120$

Ritter T., Kottke I. \& Oberwinkler F. (1986) Nachweis der vitalität von mykorrhizen durch FDA-vitalfluorochromierung. Biol. Zeit 16, 179 . 185

Ritter T., Weber G., Kottke I. \& Oberwindkler F. (1989) Zur mykorrhizaentwicklung von fichten und tannen in geschädigten beständen. Biol. Zeit 19, 9-15

Rotman B. \& Papermaster B.W. (1966) Membrane properties of living mammalian cells as studied by enzymatic hydrolysis of fluorogenic esters. Proc. Natl. Acad. Sci. USA 55, 134-141

Söderström B.E. \& Baåth E. (1978) Soil fungi in three Swedish coniferous forests. Holartic Ecol. 1, 62-72

Ziegler G.B., Ziegler E. \& Witzenhausen R. (1975) Nachweis der stoffwechselaktivität von mikroorganismen durch vital-fluorochromierung mit 3',6'diacetylfluorescein. Zentralbl. Bakteriol. Parasitenkd. Infektionskr. Hyg. Abt. 1 Orig. A 230, 252-264 